\title{
Tantangan dan Kendala Pengendalian African Swine Fever (ASF)
}

\section{Challenges and Barriers to African Swine Fever (ASF) Control}

\author{
Roza Azizah Primatika ${ }^{1}$, Etih Sudarnika $^{2 *}$, Bambang Sumiarto ${ }^{3}$, Chaerul Basri ${ }^{2}$ \\ ${ }^{1}$ Program Studi Kesehatan Masyarakat Veteriner, Fakultas Kedokteran Hewan, \\ Institut Pertanian Bogor, Jawa Barat \\ ${ }^{2}$ Departemen Kesehatan Masyarakat Veteriner, Fakultas Kedokteran Hewan, \\ Institut Pertanian Bogor, Jawa Barat \\ ${ }^{3}$ Departemen Kesehatan Masyarakat Veteriner, Universitas Gadjah Mada, Yogyakarta \\ Email: etih@apps.ipb.ac.id
}

Naskah diterima: 4 November 2020, direvisi: 17 Desember 2020, disetujui: 12 Januari 2021

\begin{abstract}
African Swine Fever (ASF) is a highly contagious hemorrhagic viral disease that attacks pigs and wild pigs causing economic losses for farms on a small and large scale. ASF outbreaks that occurred in several regions in the world have caused unrest for the livestock sector. The quick spread ASF virus has resulted in very high pig mortality. ASF virus transmission can occur through the use of swillfeeding, illegal animal products, traffic of pigs, vehicles contaminated with ASF, and the movement of wild boar. The ASF virus has three transmission cycles, namely the sylvatic, domestic, and wild boar cycles. The challenges in vaccine manufacture and development have not been found to be of particular concern to researchers to prevent the ASF virus in pigs. The obstacle faced by the government is monitoring animal products and the movement of animal traffic, while the problem with pig farming is the use of swill feeding without cooking by breeders, which is one of the factors that has not been resolved until now. ASF outbreak control and prevention that can be applied is the establishment of policies in action to break the ASF chain of transmission; securing free areas, suspected areas and infected areas; eradication in infected areas and epidemic areas; rapid response in suspected areas, infected areas, or outbreak areas; and early warning in free and infected areas.
\end{abstract}

Keywords: African swine fever; transmission route; challenges and barriers; control and prevention

\begin{abstract}
Abstrak
African Swine Fever (ASF) atau demam babi afrika merupakan penyakit viral hemoragik yang sangat menular menyerang ternak babi dan babi liar menyebabkan kerugian ekonomi bagi peternakan skala kecil dan besar. Wabah ASF yang terjadi di beberapa wilayah di dunia menimbulkan keresahan bagi sektor peternakan. Penyebaran virus ASF yang sangat cepat mengakibatkan tingkat kematian babi yang sangat tinggi. Penularan virus ASF dapat terjadi melalui penggunaan swillfeeding, produk hewan ilegal, lalu lintas ternak babi, kendaraan yang terkontaminasi ASF, dan pergerakan babi hutan. Virus ASF mempunyai tiga siklus transmisi, yaitu siklus silvatik, domestik, dan babi hutan. Tantangan dalam pembuatan dan pengembangan vaksin hingga saat ini belum ditemukan menjadi perhatian khusus bagi peneliti untuk mencegah virus ASF pada babi. Kendala yang dihadapi oleh pemerintah adalah melakukan pengawasan produk hewan dan pergerakan lalu lintas hewan, sedangkan kendala pada peternakan babi adalah adanya penggunaan swill feeding tanpa pemasakan oleh peternak yang merupakan salah satu faktor yang belum dapat diatasi hingga saat ini. Pengendalian dan penanggulangan wabah ASF yang dapat diterapkan adalah penetapan kebijakan dalam tindakan memutus mata rantai penularan ASF; pengamanan daerah bebas, daerah terduga, dan daerah tertular; pemberantasan di daerah tertular dan daerah wabah; respon cepat di daerah terduga, daerah tertular, atau daerah wabah; dan peringatan dini di daerah bebas dan tertular.
\end{abstract}

Kata kunci: African swine fever; pengendalian dan penanggulangan, rute penularan; tantangan dan kendala 


\section{Pendahuluan}

Penyakit African Swine Fever yang selanjutnya disingkat dengan (ASF) merupakan penyakit viral hemoragik yang sangat menular menyerang ternak babi dan babi liar dengan tingkat kematian yang sangat tinggi dengan waktu kematian 2 - 10 hari (FAO 2009) dan tidak bersifat zoonosis (Penrith 2013). Virus African Swine Fever (ASFV) berasal dari Sub-Sahara Afrika yang diduga berasal dari babi hutan yang telah menularkan ke babi peliharaan (Dixon et al., 2019). Infeksi dengan strain yang ganas biasanya menyebabkan ASF kronis, per-akut hingga akut dengan tanda-tanda kematian mendadak, demam tinggi, serta pendarahan di kulit dan organ dalam. Babi biasanya mati dalam tiga hingga sepuluh hari setelah infeksi dengan tingkat kematian 90\% atau lebih (Chenais et al., 2019). Vaksin ASF sampai saat ini belum tersedia. Strategi pengendalian penyakit tergantung deteksi dini penyakit dan penerapan biosekuriti yang ketat (Yoo et al., 2020). Selain sanitasi ternak, pengendalian wabah ASF dilakukan dengan memberantas ternak yang terinfeksi dan mengkarantina daerah yang terkena dampak (de Carvalho Ferreira et al., 2013).

Penyakit ini menyebabkan kerugian ekonomi yang cukup besar karena mengancam keamanan pangan dan perdagangan secara global dimana sektor peternakan babi merupakan peran kunci sebagai sumber protein hewani (Beltrán-Alcrudo et al., 2017). Dampak dan tantangan produksi babi sangat berpengaruh kepada negara - negara pengimpor babi. Sejak kemunculan ASF di Georgia pada 2007, penyakit ini telah menyebar ke banyak negara di Eropa dan pada 2018 yang terdeteksi di Asia Timur dimana lebih dari 60 persen menyerang babi domestik (Guberti et al., 2019). Di Negara berkembang, peternakan babi sebagian besar dipelihara secara tradisional, dengan skala kecil untuk memenuhi kebutuhan pangan rumah tangga. Fungsi pemeliharaan babi tidak hanya sebagai tambahan protein melainkan sumber pendapatan dengan penjualan sebagai biaya sekolah, berobat, dan investasi kecil oleh peternak (Beltrán-Alcrudo et al., 2017). Dampak penyakit ini dapat dilihat dari kerugian yang dihitung berdasarkan jumlah hewan yang mati dari peternakan yang terinfeksi wabah ASF (Mebus 2020). Wabah penyakit ASF yang terjadi di beberapa Negara termasuk
Indonesia merupakan permasalahan yang belum teratasi. Tujuan dari review artikel ini adalah untuk mengetahui transmisi dan patogenesis, diagnosa klinis, tantangan dan kendala mengenai strategi pengendalian dan pengembangan vaksin penyakit African Swine Fever.

\section{Materi dan Metode}

Desain penelitian yang masuk dalam review artikel ini menggunakan eksperimen dan literatur studi. Jenis metode penelitian ini adalah metode terbaik dalam menjawab pertanyaan klinis di lapangan. Tipe studi yang direview adalah semua jenis penelitian yang membahas mengenai African Swine Fever (ASF). Literature review ini disusun melalui penelusuran artikel penelitian yang sudah terpublikasi. Penelusuran dilakukan menggunakan Google search dan Science direct dengan kata kunci tiap variabel yang dipilih. Intervensi yang masuk dalam kriteria inklusi adalah intervensi mengenai virus ASF, transmisi dan patogenesis ASF, diagnosa klinis ASF, strategi pengendalian dan pengembangan vaksin ASF yang dilakukan. Pencarian artikel berbatas mulai dari tahun $2010-$ 2020 yang diakses fulltext dalam format pdf.

\section{Hasil dan Pembahasan}

\section{Virus African Swine Fever (ASFV)}

Virus African Swine Fever (ASFV) adalah virus besar yang berisi DNA beruntai ganda yang membentuk genom dengan panjang sekitar 190 kbp. Virus ASF berada dalam genus Asfivirus dari keluarga Asfarviridae. virus ASF memiliki struktur icosahedral yang kompleks dikelilingi oleh lapisan membran dan memiliki diameter sekitar $200 \mathrm{~nm}$. Inti virus terdiri dari nukleoprotein yang dikelilingi oleh protein matriks. Inti dan matriks dikelilingi oleh lapisan kapsid membran bagian dalam. Lapisan kapsid yang tersusun atas protein kapsid (p72) memiliki simetri ikosahedral dan dilapisi oleh membran luar (Yoo et al., 2020).

Kejadian ASF di Afrika Timur dan Selatan merupakan siklus silvatik yang melibatkan caplak genus Ornithodoros dan babi liar Afrika (Phacochoerus spp.) yang terinfeksi secara asimptomatis (Wade et al., 2019). Virus ASF pada daerah endemik terdapat dua siklus yaitu siklus babi hutan dan siklus babi domestik di mana virus bertahan 
pada babi domestik tanpa adanya inang vertebrata atau invertebrate (Jori et al., 2013). Di Negara bagian Eropa seperti Belgia dan Federasi Rusia, virus ASF yang bersirkulasi dengan strain sangat virulen termasuk dalam genotype II (Garigliany et al., 2019). Studi saat ini menunjukkan bahwa isolat ASFV yang beredar di Eropa Timur dan Federasi Rusia sangat ganas dan membunuh sebagian besar babi domestik dan babi hutan yang terinfeksi (Sánchez-Cordón et al., 2018). Hingga saat ini, analisis sequencing untuk virus ASF di Indonesia telah dilakukan, namun belum dipublikasi.

\section{Transmisi dan Patogenesis ASF}

Penularan virus ASF pada babi liar atau babi domestik melalui beberapa cara yaitu dapat ditularkan melalui kontak langsung (direct contact) maupun tidak langsung (indirect contact). Virus ASF dapat ditransmisikan melalui kontak langsung dengan hewan terinfeksi dan atau produk hewan yang telah terkontaminasi virus ASF (Rev et al., 2020). Fomites seperti pakaian, truk pengangkut, atau pakan persediaan menjadi sumber infeksi. Caplak Ornithodoros spp. mempunyai peran penting dalam transmisi pada babi hutan. Caplak tersebut juga dapat berperan dalam penularan di peternakan babi di sekitarnya (Animal Health Australia 2019). Penularan dapat melalui babi yang terlihat sehat secara klinis tetapi dapat menjadi sumber infeksi baru yang akut, yang berkontribusi bertahannya virus ASF pada populasi babi dengan tingkat penularan $\left(R_{0}\right)$ dalam kelompok babi di peternakan adalah sebesar 0,3 (Eblé et al., 2019). Estimasi laju transmisi penularan berkisar antara 0,45 hingga 3,63 per hari yang ditentukan berdasarkan periode infeksi minimum dan maksimum, untuk mengetahui perhitungan babi yang terinfeksi secara persisten. Sementara periode infeksi minimum berkisar antara 6 hingga 7 hari, rata-rata periode infeksi maksimum berkisar antara sekitar 20 hingga hampir 40 hari (de Carvalho Ferreira et al., 2013). Selain itu, penelitian menunjukkan siklus transmisi antara babi liar dan babi peliharaan adalah siklus penting untuk penyebaran dan pemeliharaan ASFV dalam populasi babi, sementara caplak adalah reservoir alami penting yang dapat menyebarkan dan memelihara ASFV pada populasi babi liar (Alkhamis et al., 2018) we investigated the evolutionary epidemiology of ASF virus. Transmisi virus ASF juga dapat dibawa oleh manusia sebagai pembawa virus ke peternakan babi domestik selain populasi babi hutan dan habitatnya (Chenais et al., 2019). Hasil ekskresi pada babi yaitu urine dan feses juga dapat menjadi rute penting dalam penularan ASF (Davies et al., 2017). Terdapat tiga siklus dalam transmisi virus ASF, yaitu siklus sylvatic, siklus domestic, dan siklus babi hutan. Penularan dari siklus sylvatic (babi liar Afrika) ke siklus domestik (babi peliharaan) terjadi melalui transmisi tidak langsung oleh caplak. Demikian juga penularan yang terjadi pada babi hutan, dimana babi hutan yang terinfeksi ASF masuk hingga pekarangan peternakan babi peliharaan dan terjadi kontak langsung dengan babi peliharaan tersebut (BeltranAlcrudo et al., 2017). Siklus transmisi ASF dapat dilihat pada Gambar 1.

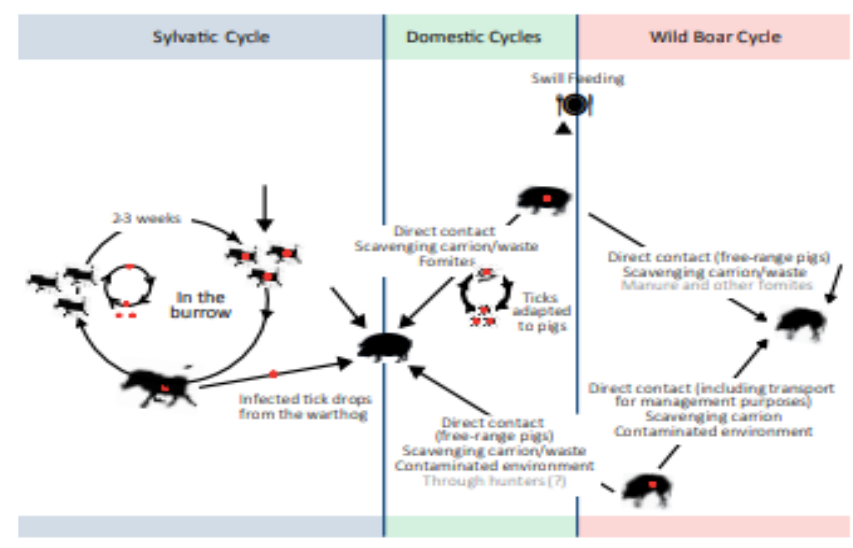

Gambar 1. Siklus transmisi virus ASF (Sumber : FAO 2017) Jalur penularan ASF melalui inhalasi dan ingesti disajikan pada Gambar 2.

Jalur penularan ASF melalui inhalasi dan ingesti disajikan pada Gambar 2.

Penelitian ASF pada babi yang ditantang dengan virus ASF strain ganas didapatkan bahwa timbulnya tanda-tanda klinis terjadi antara 1 dan 7 hari pasca inokulasi (dpi) hingga terjadi kematian dengan durasi 4-11 hari. Viremia pertama kali terdeteksi antara 4 dan 5 dpi pada semua kelompok inokulasi sedangkan ASFV yang keluar dari rongga hidung dan amandel pertama kali terdeteksi pada 3-9 dpi. Intramuscular (IM) dan kontak langsung/direct contact (DC) adalah mode infeksi yang paling konsisten. Inokulasi intranasopharyngeal (INP) menghasilkan perkembangan penyakit yang paling konsisten 
(Howey et al., 2013). Penularan dapat terjadi melalui kontak tidak langsung dengan hewan yang terinfeksi, yaitu melalui ekskresi darah yang dikeluarkan oleh hewan yang terinfeksi terutama babi hutan. Selain itu, bangkai hewan terinfeksi dapat menularkan virus ASF karena virus ASF sangat resisten dan dapat bertahan lama di bangkai terutama pada suhu rendah (EFSA 2015). Produk hewan dapat membawa virus ASF walaupun dengan cara pembekuan pada daging babi mentah beku, virus ASF dapat bertahan hingga 118 hari (Mazur-Panasiuk et al., 2019).

Mekanisme pathogenesis ASFV dalam tubuh babi memiliki pengaruh yang cukup signifikan. Penelitian yang dilakukan menyebutkan bahwa ekspresi diferensial gen menunjukkan bahwa ASFV dapat menghindari respons imun bawaan dan adaptif dengan (i) menghambat pemrosesan dan presentasi gen Major Histocompatibility Complex (MHC) Kelas II, (ii) menghindari sel efektor yaitu sel $\mathrm{T}$ sitotoksik $(\mathrm{CD} 8+\mathrm{T})$ dan perangkap ekstra-seluler neutrofil melalui penurunan ekspresi dari neutrofil/CD8 + T chemokine perekrut sel efektor, (iii) menekan aktivasi makrofag M1, (iv) menginduksi sitokin penekan kekebalan, dan (v) menghambat proses autofag makrofag dan apoptosis (Zhu et al., 2019).

\section{Diagnosa Klinis ASF}

Gejala klinis pada babi yang menderita ASF dapat dibagi menjadi 4 tahap, yaitu per akut, akut, sub akut, dan kronis. Gejala klinis per akut ditandai dengan demam tinggi $\left(41-42^{\circ} \mathrm{C}\right)$, kehilangan nafsu makan dan tidak aktif, kematian mendadak mungkin terjadi dalam 1-3 hari sebelum timbulnya tanda klinis. Gejala klinis akut di tandai jika setelah masa inkubasi 4-7 hari (jarang, hingga 14 hari), hewan menunjukkan demam $40-42^{\circ} \mathrm{C}$ dan kurang nafsu makan; hewan-hewan terlihat mengantuk dan lemah, berbaring dan meringkuk serta menunjukkan peningkatan laju pernapasan, kematian sering terjadi di dalam 6-9 hari untuk strain yang sangat virulen, atau 11-15 hari untuk isolat yang cukup virulen. Gejala subakut disebabkan oleh isolat yang cukup virulen dan dapat terjadi pada daerah endemik. Babi biasanya mati dalam 7-20 hari, dengan tingkat kematian mulai dari 30 hingga 70 persen. Fluktuasi demam, disertai oleh depresi dan kehilangan nafsu makan, juga biasa terjadi, kesakitan pada waktu berjalan dan sendi bengkak dengan akumulasi cairan dan fibrin, tanda-tanda respirasi dan pneumonia, serta keguguran pada babi betina. Gejala kronis sering mengakibatkan tingkat kematian yang biasanya kurang dari 30 persen. Bentuk kronis berasal dari

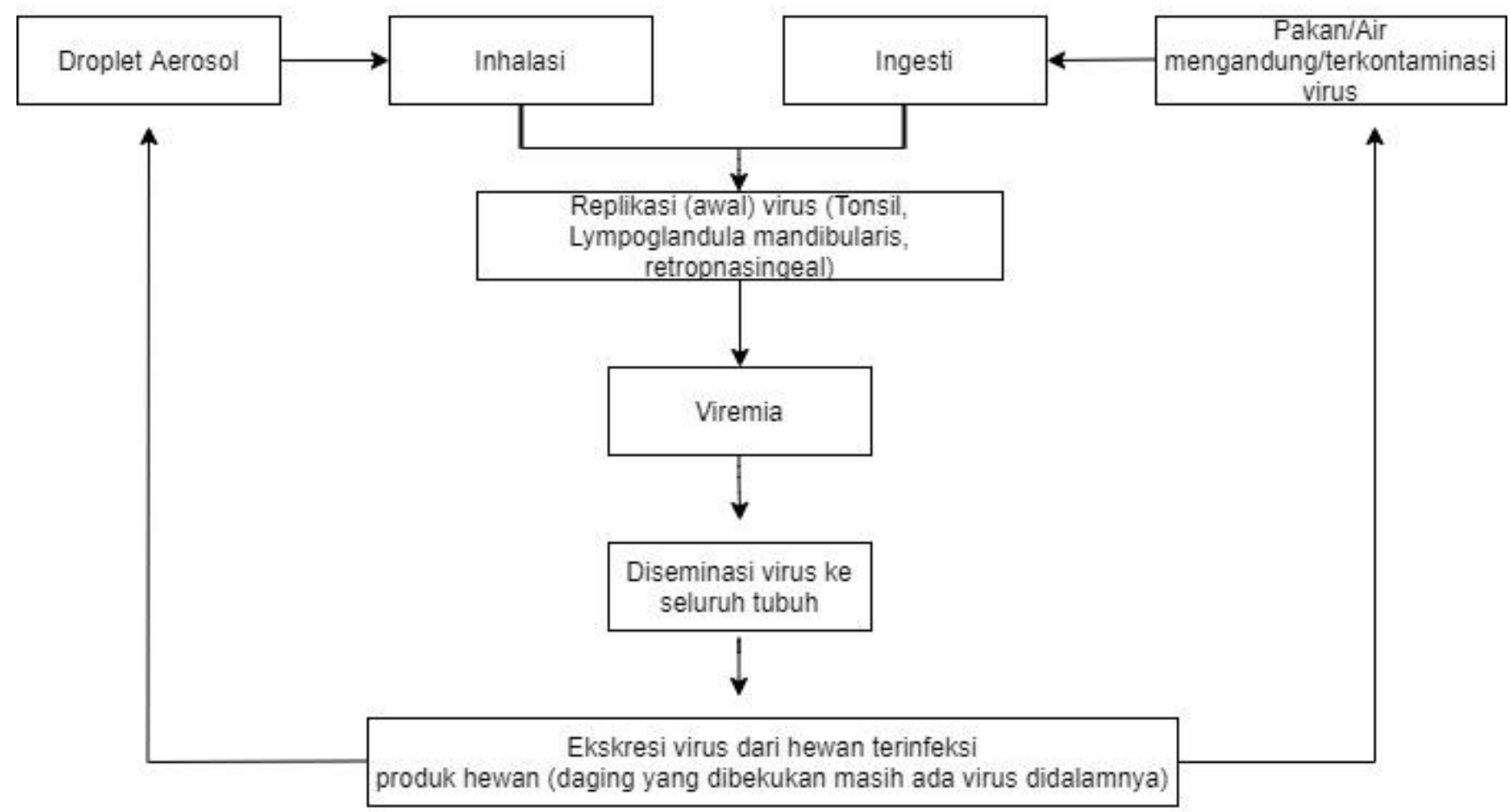

Gambar 2. Alur jalur penularan ASF (Guinat et al. 2016) 
Tabel 1. Mekanisme virus African Swine Fever (W. Antin 2020)

\begin{tabular}{|c|c|c|}
\hline \multicolumn{3}{|c|}{ Virus + respon imun $=$ pathogenesis $\rightarrow$ gejala klinis + pemeriksaan laboratorium + temuan patologis } \\
\hline $\begin{array}{l}\text { Virus African Swine Fever } \\
\text { (ASFV) }\end{array}$ & Aksi & Efek \\
\hline - Monosit & - Kerusakan monosit/makrofag dan sel turunannya & - Proses inflamasi parah \\
\hline $\begin{array}{l}\text { - Megakariosit komponen } \\
\text { seluruh darah lainnya }\end{array}$ & - Menekan pelepasan materi anti inflamasi & - Apoptosis limfosit \\
\hline \multirow[t]{4}{*}{ - Sel epitel, endotel } & - Pelepasan materi pro inflamasi & $\begin{array}{l}\text { - Vasodilatasi, meningkatnya } \\
\text { permeabilitas vascular yaitu } \\
\text { hiperemi, edema, hemoragi }\end{array}$ \\
\hline & $\begin{array}{l}\text { - Status prokoagulan dan materi pembentuk asam/ } \\
\text { Potential Acid Forming (PAF) }\end{array}$ & - Gangguan hemostatsis/koagulasi \\
\hline & - Penurunan produksi trombosit & - Kerusakan jaringan \\
\hline & - Aktivasi dan kerusakan endotel, epitel & \\
\hline
\end{tabular}

virus yang dilemahkan secara alami. Tanda-tanda klinis mulai $14-21$ hari setelah infeksi dengan sedikit demam, diikuti oleh gangguan pernapasan ringan dan pembengkakan sendi sedang sampai berat, serta dikombinasikan dengan area kulit memerah. Apabila babi dilakukan nekropsi tambahan, maka akan ditemukan pneumonia dengan nekrosis caseous di paru-paru, perikarditis fibrinosa, dan kelenjar getah bening edematosa, yang sebagian dapat berupa perdarahan (terutama kelenjar getah bening mediastinum) (BeltranAlcrudo et al., 2017).

\section{Riwayat Kasus Wabah ASF}

ASF pertama kali terjadi di Negara Kenya Afrika pada tahun 1921 yang di jelaskan bahwa penyakit ini berbeda dengan Classical Swine Fever (CSF) yang telah terjadi pada tahun 1830 silam di belahan bumi bagian Utara (Penrith 2013). Perkembangan penyakit ASF menular dan menyebar sangat cepat dan sangat luas karena karakteristik virus ASF sangat ganas yang dapat dibawa baik melalui kontak langsung maupun tidak langsung seperti yang telah dijelaskan. Penyebaran virus ASF dibeberapa Negara di

Tabel 2. Gejala klinis pada tubuh babi (Sánchez-Vizcaíno et al. 2015)

\begin{tabular}{|c|c|c|c|c|}
\hline & Per akut & Akut & Sub akut & Kronis \\
\hline Demam & Tinggi & Tinggi & Sedang & $\begin{array}{l}\text { Tidak teratur atau tidak } \\
\text { ada }\end{array}$ \\
\hline Trombositopenia & Tidak ada & Tidak ada & Sementara & Tidak ada \\
\hline Kulit & Eritema & Eritema & Eritema & Daerah nikrotik \\
\hline Kelenjar getah bening & & $\begin{array}{l}\text { Gastrohepatik dan ginjal } \\
\text { dengan } \\
\text { aspek marmer }\end{array}$ & $\begin{array}{l}\text { Mayoritas kelenjar getah bening } \\
\text { menyerupai gumpalan darah }\end{array}$ & Bengkak \\
\hline Limpa & & Splenomegali hiperemik & $\begin{array}{l}\text { Splenomegali hiperemik parsial } \\
\text { atau infark fokus }\end{array}$ & $\begin{array}{l}\text { Diperbesar dengan } \\
\text { warna normal }\end{array}$ \\
\hline Ginjal & & $\begin{array}{l}\text { Perdarahan petekie, terutama } \\
\text { di korteks }\end{array}$ & $\begin{array}{l}\text { Pendarahan petekie di korteks, } \\
\text { medula dan panggul; edema } \\
\text { perirenal }\end{array}$ & \\
\hline Paru - paru & & Edema alveolar yang parah & & Pleuritis dan pneumonia \\
\hline Kantung empedu & & Perdarahan petekie & Edema dinding & \\
\hline Hati & & $\begin{array}{l}\text { Perdarahan pada epicardium } \\
\text { dan } \\
\text { endokardium }\end{array}$ & $\begin{array}{l}\text { Perdarahan pada epicardium dan } \\
\text { endokardium; hidroperikardium }\end{array}$ & Perikarditis fibrosis \\
\hline Tonsil & & & & Fokus nekrotik \\
\hline Perubahan reproduksi & & & Keguguran & Keguguran \\
\hline
\end{tabular}


Dunia dilaporkan dengan tingkat kematian yang cukup tinggi. Peningkatan pola sebaran ASF pada beberapa tahun terakhir di beberapa Negara bagian di Dunia terjadi dalam kurun waktu yang sangat singkat dan mengakibatkan kerugian ekonomi peternak babi di wilayah wabah.

Perkembangan virus ASF 10 tahun terakhir dilaporkan pertama kali pada tahun 2007 yang terjadi di Caucasus Georgia (Costard et al., 2013). Berdasarkan penelitian yang dilakukan, analisis sekuensing wabah yang terjadi di Georgia menunjukkan bahwa isolat berhubungan erat dengan isolat genotipe II, yang beredar di Mozambique, Madagaskar, dan Zambia. Penyebaran penyakit ke Georgia ditularkan melalui pakan babi yang terkontaminasi ASFV yang dibawa oleh kapal (Rowlands et al., 2008). Kejadian wabah di Georgia tahun 2007 mengakibatkan penularan ke sebagian besar wilayah di Federasi Rusia hingga tahun 2012 yang menjadikan penyakit ini menjadi epidemic. Sumber penularan yang terjadi akibat adanya produk babi illegal dari daerah yang terkontaminasi virus ASF dan berasal dari swillfeeding yang diberikan kepada babi peliharaan (Gogin et al., 2013).

Surveilans dilakukan di dataran tinggi Tanzania sejak tahun 2010 yang mengalami kembali wabah ASF, dimana hasil yang diperoleh berdasarkan epidemiologi partisipatif eksploratori menjelaskan bahwa faktor risiko ASF meliputi sistem perdagangan dan pemasaran, sistem manajemen, dan kurangnya biosekuriti, serta masalah antropogenik (manusia), hewan dan fomite (Fasina et al., 2020). Setelah wabah ASF menyebar di Negara Federasi Rusia, pada tahun 2014 terjadi kembali wabah di Negara Uni Eropa (UE) dimana peternakan dengan biosekuriti yang rendah sangat mudah terinfeksi virus ini. Tiga sifat epidemiologi ASF yang terjadi di Negara Uni Eropa ini meliputi penularan, ketahanan virus, dan tingkat fatalitas kasus yang tinggi (Chenais et al., 2019). Wabah yang terjadi di Latvia pada tahun 2014 mengakibatkan kematian 32 babi peliharaan dan 217 babi hutan, dimana penularan pada babi peliharaan terjadi akibat adanya biosekuriti pada pemberian pakan yang telah terkontaminasi virus ASF. Sedangkan penularan pada babi hutan terjadi akibat memakan bangkai babi hutan yang telah terinfeksi. Prevalensi pada babi peliharaan lebih rendah daripada babi hutan karena adanya pola biosekuriti yang berbeda (Guberti et al., 2016). Banyak faktor yang mempengaruhi terjadinya ASF di Federasi Rusia dan Uni Eropa, yaitu adanya biosekuriti yang sangat rendah, pemberian swillfeeding secara tradisional, adanya pergerakan lalu lintas yang sulit untuk dikendalikan seperti pergerakan babi hutan, pergerakan hewan dan produk-produk hewan ilegal serta pergerakan kendaraan yang terkontaminasi atau fomites lainnya (Sa et al., 2013). Pada tahun 2018, wabah ASF terjadi kembali di daerah Uni Eropa tepatnya di daerah Slovakia pada periode bulan November 2018 hingga Oktober 2019. Salah satu faktor yang mempengaruhi terjadinya wabah ini adalah adanya perubahan musim panas yang diketahui meningkatkan jumlah kejadian ASF. Pengendalian yang dilakukan pada wabah di Slovakia adalah memasang pagar agar dapat menghalangi babi hutan masuk ke peternakan babi peliharaan yang membawa virus ASF (Miteva et al., 2020).

Penyebaran wabah ASF terjadi sepanjang tahun 2019 hingga tahun 2020 yang meliputi hampir wilayah di seluruh dunia meliputi daerah bagian Asia. Tahun 2019, wabah ASF terjadi di peternakan babi milik keluarga di Provinsi Hung Yen, Vietnam. Gejala yang dialami pada tahap awal wabah, 1 anak babi dan 1 betina menunjukkan kemerahan di seluruh tubuh, konjungtivitis, dan diare hemoragik serta menunjukkan anoreksia, sianosis, dan demam $\left(>40,5^{\circ} \mathrm{C}\right)$ (Le et al., 2019). Bermula kejadian wabah ASF di Vietnam, penyebaran terjadi hampir di bagian Asia yaitu Indonesia, Filipina, Timor Leste. Tahun 2019 wabah terjadi di Medan Sumatra Utara, Indonesia dengan kasus sebanyak 465 diikuti negara Filipina sebanyak 130 kasus pada 10 wilayah admnistratif yang berbeda (Mebus 2020). Hingga saat ini wabah masih terjadi di sebagian besar daerah Asia seperti China, Myanmar, Papua Nugini, Laos. Pada bulan Februari tahun 2020, wabah ASF terjadi di China dengan jumlah 124 wabah dan 26 wabah pada bulan maret di Negara Timor Leste. Penyebaran berlanjut di Negara Filipina pada bulan Maret 2020 dengan jumlah kasus sebanyak 69 wabah di 15 wilayah administratif yang berbeda (OIE 2020a). Pada bulan Maret hingga April 2020, Wabah diikuti di beberapa Negara di Asia Korea sebanyak 54 kasus yang menyerang 
babi hutan, dan pertama kali di Negara Papua Nugini dikonfirmasi terjadi wabah ASF (Mebus 2020). Wabah ASF masih berlangsung hingga bulan Mei 2020, dimana kejadian ASF terjadi di beberapa wilayah Asia, yaitu India sebanyak 11 kasus dan Korea sebanyak 14 kasus pada babi liar (OIE 2020b). Kejadian yang belum dilaporkan hingga saat ini adalah wabah ASF di Provinsi Nusa Tenggara Timur, Indonesia yang telah terjadi pada bulan Maret 2020 hingga mencapai puluhan ribu ekor (FAO 2020a).

\section{Strategi Pengendalian ASF}

Upaya pengendalian ASF yang dapat dilakukan oleh beberapa negara adalah melakukan peningkatan karantina dan biosekuriti yang ketat, membatasi lalu lintas babi dan pengurangan populasi ternak babi yang sakit dan terpapar. Disamping penerapan biosekuriti yang baik, mengurangi kontak dengan pakan/alat yang tercemar seperti penggunaan swill feeding sebagai pakan ternak babi dan pengolahan limbah pesawat, serta pengetatan barang bawaan penumpang pesawat dan kapal laut perlu dilakukan (Sendow et al., 2020).

Pencegahan yang dilakukan di negara Eropa, dilakukan berdasarkan pada sektor peternakan babi yang dibagi menjadi tiga sektor, yaitu peternakan komersial, non komersial, dan diliarkan. Identifikasi oleh Ahli ASF mengenai tiga sektor peternakan adalah identifikasi hewan dan catatan peternakan, penegakan hukum yang ketat terhadap larangan mencuci makanan, serta penahanan babi, sehingga tidak memungkinkan kontak langsung atau tidak langsung antara babi-babi dan/atau babi-babi hutan. Tindakan pencegahan penting lainnya untuk semua pertanian adalah pendidikan petani, pekerja, dan operator; tidak ada kontak antara petani dan staf peternakan dan babi eksternal; pembuangan bangkai, residu penyembelihan, dan sisa makanan secara tepat; pembuangan kotoran hewan dan hewan mati dengan benar, dan tidak melakukan aktivitas berburu selama 48 jam sebelumnya (memungkinkan interval 48 jam antara berburu dan bersentuhan dengan babi peliharaan). Selain itu, tindakan pencegahan yang dilakukan pada peternakan non-komersial dan liar adalah untuk meningkatkan akses peternakan ke dokter hewan dan layanan kesehatan (Jurado et al., 2018).
Peningkatan biosekuriti di peternakan setelah adanya wabah di Uganda juga ditingkatkan dengan batasan yang diberikan pada zona bersih dan zona kotor. Pemisahan zona bersih dan zona kotor bertujuan untuk menghindari cemaran baik baik bakteri maupun virus yang berasal dari zona kotor ke zona bersih. Penyembelihan babi tidak dapat dilakukan di zona bersih dan pekerja pada penyembelihan tidak boleh melakukan pekerjaan di zona bersih (Bössfall 2015). Upaya pemberantasan yang dapat dilakukan di negara Afrika adalah dengan mengidentifikasi faktor risiko terjadinya ASF. Faktor risiko tersebut antara lain adalah populasi babi yang besar, sistem peternakan tradisional (dilepasliarkan), kurangnya biosekuriti dalam sistem peternakan semi intensif dan intensif, kurangnya organisasi dalam produksi babi dan pemasaran babi yang mengakibatkan kurangnya insentif untuk investasi dalam peternakan babi, serta manajemen ASF yang tidak efektif. Sebagian besar faktor ini terkait dengan kemiskinan, namun babi diakui sebagai spesies ternak yang dapat digunakan untuk meningkatkan mata pencaharian dan berkontribusi secara signifikan terhadap ketahanan pangan (Penrith et al., 2013).

Pengelolaan pakan terkait pemberian swill feeding atau pakan sisa harus diberikan dengan pengolahan yang baik (Kementan 2019). Walaupun dilakukan pelarangan pemberian swill feeding untuk babi, namun hal ini masih dilakukan oleh peternak akibat tingkat ekonomi peternak yang rendah dan sebagai mata pencaharian peternak babi (FAO 2020b). Pengelolaan manajemen swill feeding yang baik meliputi adanya larangan secara hukum, adanya perijinan pada bahan-bahan aman yang teridentifikasi di swill feeding, proses menonaktifkan pathogen yang relevan (Penrith 2020). Penonaktifan pathogen dalam swill feeding dapat dilakukan dengan pengolahan limbah pakan dengan cara perebusan minimal 30 menit (BeltránAlcrudo 2014).

\section{Pengembangan Vaksin Virus African Swine Fever (ASFV)}

Virus ASF merupakan virus yang sangat virulen dan dapat menganggu jalur signal seluler yang menghasilkan imunomodulasi, sehingga membuat pengembangan vaksin yang efektif sangat menantang. Virus ASF yang di nonaktifkan 
tidak memberi perlindungan dan peran antibodi pada babi. Penggunaan vaksin memberikan tingkat perlindungan tergantung pada hewan yang divaksinasi meliputi keamanan dan efek samping vaksin. Beberapa protein virus ASF telah dikembangkan untuk menginduksi antibodi penetralisasi pada babi yang divaksin. Selain itu, strategi vaksinasi berdasarkan vaksin DNA dan protein rekombinan telah dieksplorasi, namun terjadi kegagalan. Kompleksitas partikel virus dan kemampuan virus memodulasi respons imun inang kemungkinan besar menjadi alasan kegagalan ini. Disamping itu, kultur sel permanen tidak ada yang mampu mempertahankan infeksi virus produktif oleh strain virus ASF yang virulen (Revilla et al., 2018).

Keseimbangan yang tepat antara respons imun ASFV yang dimediasi antara antibodi dan sel jelas penting. Rangsangan terhadap kekebalan menjadi faktor kunci yang mempengaruhi perjalanan penyakit ASF dan tingkat antibodi yang tinggi tampaknya memiliki efek yang sangat merugikan pada hasil klinis. Jenis antibodi dapat ditentukan dengan memilih dan mengidentifikasi epitop. Epitop netralisasi dan non-netralisasi dalam antigen dapat bermanfaat untuk merancang respon imun untuk meningkatkan perlindungan pada individu. Meskipun demikian, induksi imunitas yang dimediasi sel yang kuat, seperti respons Natural Killer (NK) dan sel T, tampaknya tetap merupakan komponen penting untuk merancang vaksin ASFV yang aman dan berhasil (Gaudreault dan Richt 2019).

Saat ini strategi pengembangan vaksin dengan menggunakan DIVA (Differentiating Infected from Vaccinated Animals) untuk membedakan antara virus hasil vaksinasi dan infeksi alami virus ASF pada babi harus dilakukan secara paralel dengan pengembangan vaksin yang lainnya (Sánchez et al., 2019). Selain itu, penelitian terbaru melakukan urutan genom pada babi hutan spesies warthog (Phacocherus africanus) dan babi hutan (Potamochoerus larvatus) untuk lebih memahami mekanisme terhadap infeksi ASFV dibandingkan dengan babi domestik untuk pengembangan pembuatan vaksin (Sang et al., 2020). Beberapa strategi dalam pengembangan vaksin yang dapat dilakukan adalah vaksin tidak aktif (inactived vaccines), vaksin yang dilemahkan secara lang- sung (Live-attenuated vaccines/LAV), Vaksin subunit (Subunit Vaccines), Vaksin DNA (DNA Vaccines), Vaksin virus-vektor hidup (Live virusvectored vaccines), LAV rekombinan (Vaksin yang menghapus gen/Gene-deleted vaccines) (Hua-Ji 2019). Inactived vaccines memiliki kelemahan dimana tidak menghasilkan kekebalan dan tidak memberikan perlindungan terhadap virus ASF bahkan dengan adanya adjuvant. Pengembangan vaksin dengan menggunakan Live-attenuated vaccines (LAV) akan menstimulasi imunitas seluler dan humoral bawaan dan sekunder, meskipun LAV harus dilemahkan dengan modifikasi gen virus. Vaksin subunit dikembangkan dengan mengkloning gen virus p30 dan p54 yang dikombinasikan vaksinasi babi dengan DNA yang mengkode domain ekstraseluler hemagglutinin (HA) ASFV menyebabkan perbaikan baik pada respon imun seluler maupun humoral, meskipun tidak memberikan perlindungan (Sánchez et al., 2019). Vaksin DNA yang dikembangkan belum memberikan perlindungan yang baik. Sedangkan Live virus-vectored vaccines dengan menggunakan vector Adenovirus mempunyai perlindungan secara parsial. Pengembangan LAV rekombinan mempunyai perlindungan silang berdasarkan pada strain virulen atau isolat alami yang dilemahkan (Hua-Ji 2019).

\section{Kesimpulan}

African Swine Fever (ASF) merupakan penyakit viral hemoragik yang menyerang ternak babi dan babi liar yang sangat menular dengan tingkat mortalitas yang sangat tinggi dan menyebabkan kerugian ekonomi bagi peternak baik peternakan skala kecil maupun besar. Penularan virus ASF dapat terjadi melalui penggunaan swillfeeding, produk hewan ilegal, lalu lintas ternak babi, kendaraan yang terkontaminasi ASF, dan pergerakan babi hutan. Terdapat tiga siklus dalam transmisi virus ASF, yaitu siklus sylvatic, siklus domestic, dan siklus babi hutan.

Tantangan dalam pembuatan dan pengembangan vaksin hingga saat ini belum ditemukan, sehingga menjadi perhatian khusus bagi peneliti untuk mencegah virus ASF pada babi. Kendala yang dihadapi oleh pemerintah adalah melakukan pengawasan produk hewan dan pergerakan lalu lintas hewan, sedangkan kendala pada 
peternakan babi adalah adanya penggunaan swill feeding tanpa pemasakan oleh peternak. Hal ini merupakan salah satu faktor yang belum dapat diatasi hingga saat ini. Penerapan strategi yang dapat dilakukan ketika penetapan status wabah ASF adalah berdasarkan amanat Peraturan Pemerintah No.47 tentang Pengendalian dan Penanggulangan Penyakit Hewan pasal 20 Tahun 2014. Pengendalian dan penanggulangan yang diterapkan adalah penetapan kebijakan dalam tindakan memutus mata rantai penularan ASF; pengamanan daerah bebas, daerah terduga, dan daerah tertular; pemberantasan di daerah tertular dan daerah wabah; respon cepat di daerah terduga, daerah tertular, atau daerah Wabah; dan peringatan dini di daerah bebas dan tertular.

\section{Daftar Pustaka}

[FAO]. Food Agriculture Organization of the United Nations. 2017. African Swine Fever: Detection And Diagnosis (a manual for veterinarians). [internet]. [diacu 4 Juni 2020]. Tersedia di http://www.fao.org/3/ai7228e.pdf

[OIE]. Office International Epizooties/World Organization for Animal Health. 2020. General situation of ASF in Asia and the Pacific. [internet]. [diacu 27 Mei 2020]. Tersedia di https://rr-asia.oie.int/en/projects/asf/situational-updates-of-asf/

Alkhamis MA, Gallardo C, Jurado C, Soler A, Arias M, Sánchez-Vizcaíno JM. 2018. Phylodynamics and evolutionary epidemiology of African swine fever p72CVR genes in Eurasia and Africa. PLoS One. 13(2):1-18. doi:10.1371/journal. pone. 0192565 .

Animal Health Australia. 2019. Disease Strategy - African swine fever. Ausvetplan.(March).

Beltrán-Alcrudo D. 2014. Recommendations for the prevention and control of african swine fever in at-risk countries I.

Beltrán-Alcrudo D, Arias M, Gallardo C, Kramer S\&, Penrith ML. 2017. African swine fever (ASF) detection and diagnosis.

Beltran-Alcrudo D, Arias M, Gallardo C, Kramer SA, Penrith M-L. 2017. African swine fever
(ASF) detection and diagnosis-A manual for veterinarians. Volume ke-19.

Bössfall C. 2015. Herd biosecurity in smallholder settings With focus of African swine fever in Uganda.

de Carvalho Ferreira HC, Backer JA, Weesendorp E, Klinkenberg D, Stegeman JA, Loeffen WLA. 2013. Transmission rate of African swine fever virus under experimental conditions. Vet Microbiol. 165(3-4):296304. doi:10.1016/j.vetmic.2013.03.026.

Chenais E, Depner K, Guberti V, Dietze K, Viltrop A, Ståhl K. 2019. Epidemiological considerations on African swine fever in Europe 2014-2018. Porc Heal Manag. 5(1):1-10. doi:10.1186/s40813-018-0109-2.

Costard S, Mur L, Lubroth J, Sanchez-vizcaino JM, Pfeiffer DU. 2013. Epidemiology of African swine fever virus. Virus Res. 173(1):191197. doi:10.1016/j.virusres.2012.10.030.

Davies K, Goatley LC, Guinat C, Netherton CL, Gubbins S, Dixon LK, Reis AL. 2017. Survival of African Swine Fever Virus in Excretions from Pigs Experimentally Infected with the Georgia 2007/1 Isolate. Transbound Emerg Dis. 64(2):425-431. doi:10.1111/tbed.12381.

Dixon LK, Sun H, Roberts H. 2019. African swine fever. Antiviral Res. 165:34-41. doi:10.1016/j.antiviral.2019.02.018.

Eblé PL, Hagenaars TJ, Weesendorp E, Quak S, Moonen-Leusen HW, Loeffen WLA. 2019. Transmission of African Swine Fever Virus via carrier (survivor) pigs does occur. Vet Microbiol. 237(February):108345. doi:10.1016/j.vetmic.2019.06.018.

EFSA. 2015. African swine fever. EFSA (European Food Saf Authority) J. 13(7). doi:10.2903/j. efsa.2015.4163.

FAO. 2009. African swine fever General Disease Information Sheets What is African swine fever? General Disease Information Sheets Where is the disease found? Anim Heal.: $1-6$.

FAO. 2020a. ASF situation in Asia update. 
FAO. 2020b. Prevention strategies for ASF. : Chapter 4.

Fasina FO, Kissinga H, Mlowe F, Mshang'a S, Matogo B, Mrema A, Mhagama A, Makungu S, Mtui-Malamsha N, Sallu R, et al., 2020. Drivers, risk factors and dynamics of african swine fever outbreaks, southern highlands, Tanzania. Pathogens. 9(3):1-18. doi:10.3390/pathogens 9030155 .

Garigliany M, Desmecht D, Tignon M, Cassart D, Lesenfant C, Paternostre J, Volpe R, Cay AB, van den Berg T, Linden A. 2019. Phylogeographic analysis of African swine fever virus, Western Europe, 2018. Emerg Infect Dis. 25(1):184-186. doi:10.3201/ eid2501.181535.

Gaudreault NN, Richt JA. 2019. Subunit vaccine approaches for African swine fever virus. Vaccines. 7(2). doi:10.3390/ vaccines 7020056.

Gogin A, Gerasimov V, Malogolovkin A, Kolbasov D. 2013. African swine fever in the North Caucasus region and the Russian Federation in years 2007-2012. Virus Res. 173(1):198203. doi:10.1016/j.virusres.2012.12.007.

Guberti V, Khomenko S, Masiulis M, Kerba S. 2019. African swine fever in wild boar: ecology and biosecurity.

Guberti V, Westergaard J, Gallardo C, Rodze I, Depner K. 2016. Research in Veterinary Science African swine fever virus introduction into the EU in 2014 : Experience of Latvia. 105:28-30. doi:10.1016/j. rvsc.2016.01.006.

Guinat C, Gogin A, Blome S, Keil G, Pollin R, Pfeiffer DU, Dixon L. 2016. Transmission routes of African swine fever virus to domestic pigs: Current knowledge and future research directions. Vet Rec. 178(11):262-267. doi:10.1136/vr.103593.

Howey EB, O’Donnell V, de Carvalho Ferreira HC, Borca M V., Arzt J. 2013. Pathogenesis of highly virulent African swine fever virus in domestic pigs exposed via intraoropharyngeal, intranasopharyngeal, and intramuscular inoculation, and by direct contact with infected pigs. Virus Res. 178(2):328-339. doi:10.1016/j. virusres.2013.09.024.

Hua-Ji Q. 2019. African swine fever vaccines: Current situation and perspectives.

Jori F, Vial L, Penrith ML, Pérez-Sánchez R, Etter E, Albina E, Michaud V, Roger F. 2013. Review of the sylvatic cycle of African swine fever in sub-Saharan Africa and the Indian ocean. Virus Res. 173(1):212-227. doi:10.1016/j.virusres.2012.10.005.

Jurado C, Martínez-Avilés M, Torre AD La, Štukelj M, Ferreira HC de C, Cerioli M, Sánchez-Vizcaíno JM, Bellini S. 2018. Relevant measures to prevent the spread of African Swine Fever in the European Union Domestic Pig Sector. Front Vet Sci. 5(APR). doi:10.3389/fvets.2018.00077.

Kementan. 2019. Kiat vetindo asf.

Le VP, Jeong DG, Yoon S, Kwon H, Bich T, Trinh $\mathrm{N}$, Nguyen TL, To T, Bui N, Oh J, et al., 2019. Outbreak of African Swine Fever, Vietnam, 2019. 25(7):2017-2019.

Mazur-Panasiuk N, Żmudzki J, Woźniakowski G. 2019. African swine fever virus - persistence in different environmental conditions and the possibility of its indirect transmission. $J$ Vet Res. 63(3):303-310. doi:10.2478/ jvetres-2019-0058.

Mebus CA. 2020. African swine fever. Adv Virus Res. 35(C):251-269. doi:10.1016/S00653527(08)60714-9.

Miteva A, Papanikolaou A, Gogin A, Boklund A, Bøtner A, Linden A, Viltrop A, Schmidt CG, Ivanciu C, Desmecht D, et al., 2020. Epidemiological analyses of African swine fever in the European Union (November 2018 to October 2019). EFSA J. 18(1):1107. doi:10.2903/j.efsa.2020.5996.

OIE. 2020a. African Swine Fever ( ASF ) Report $N^{\circ} 40$ : March 13-26 , 2020 World Animal Health Information and Analysis Department. 1:2020.

OIE. 2020b. African Swine Fever (ASF) Report $N^{\circ}$ 18: May 10-23. 1:2019. 
Penrith ML. 2013. History of "swine fever" in Southern Africa. J S Afr Vet Assoc. 84(1). doi:10.4102/jsava.v84i1.1106.

Penrith ML. 2020. Management options to mitigate the risk of swill feeding. 1.

Penrith ML, Vosloo W, Jori F, Bastos ADS. 2013. African swine fever virus eradication in Africa. Virus Res. 173(1):228-246. doi:10.1016/j.virusres.2012.10.011.

Rev A, Biosci A, Dixon LK, Stahl K, Jori F, Vial L, Pfeiffer DU. 2020. African Swine Fever Epidemiology and Control. :1-26.

Revilla Y, Pérez-Núñez D, Richt JA. 2018. African Swine Fever Virus Biology and Vaccine Approaches. Adv Virus Res. 100:41-74. doi:10.1016/bs.aivir.2017.10.002.

Rowlands RJ, Michaud V, Heath L, Hutchings G, Oura C, Vosloo W, Dwarka R, Onashvili T, Albina E, Dixon LK. 2008. African swine fever virus isolate, Georgia, 2007. Emerg Infect Dis. 14(12):1870-1874. doi:10.3201/ eid1412.080591.

Sa M, Mur L, Martı B. 2013. African swine fever (ASF ): Five years around Europe. 165:4550. doi:10.1016/j.vetmic.2012.11.030.

Sánchez-Cordón PJ, Montoya M, Reis AL, Dixon LK. 2018. African swine fever: A reemerging viral disease threatening the global pig industry. Vet J. 233(January):41-48. doi:10.1016/j.tvj1.2017.12.025.

Sánchez-Vizcaíno JM, Mur L, Gomez-Villamandos JC, Carrasco L. 2015. An update on the epidemiology and pathology of African swine fever. J Comp Pathol. 152(1):9-21. doi:10.1016/j.jcpa.2014.09.003.

Sánchez EG, Pérez-Núñez D, Revilla Y. 2019. Development of vaccines against African swine fever virus. Virus Res. 265(March):150-155. doi:10.1016/j. virusres.2019.03.022.
Sang H, Miller G, Lokhandwala S, Sangewar N, Waghela SD, Bishop RP, Mwangi W. 2020. Progress Toward Development of Effective and Safe African Swine Fever Virus Vaccines. Front Vet Sci. 7(February):1-9. doi:10.3389/fvets.2020.00084.

Sendow I, Ratnawati A, Dharmayanti NI, Saepulloh M. 2020. African Swine Fever: Penyakit Emerging yang Mengancam Peternakan Babi di Dunia. Indones Bull Anim Vet Sci. 30(1):15. doi:10.14334/ wartazoa.v30i1.2479.

Wade A, Achenbach JE, Gallardo C, Settypalli TBK, Souley A, Djonwe G, Loitsch A, Dauphin G, Justin J, Ngang E, et al., 2019. Genetic characterization of African swine fever virus in Cameroon , 2010 - 2018. (April):2010-2018. doi:10.1007/s12275019-8457-4.

Yoo D, Kim H, Lee JY, Yoo HS. 2020. African swine fever: Etiology, epidemiological status in Korea, and perspective on control. J Vet Sci. 21(2):1-24. doi:10.4142/ JVS.2020.21.E38.

Zhu JJ, Ramanathan P, Bishop EA, O’Donnell V, Gladue DP, Borca M V. 2019. Mechanisms of African swine fever virus pathogenesis and immune evasion inferred from gene expression changes in infected swine macrophages. PLoS One. 14(11):1-22. doi:10.1371/journal.pone.0223955.

W, Antin, N.Y. 2020. Perkembangan Wabah ASF : Diagnosa Klinis dan Patologis Penyakit ASF. Webinar Halovet 23 Mei 2020. [internet]. [diacu pada tanggal 23 Mei 2020]. 